\title{
Reference Books of 1975-76: A Selection
}

These books have been examined and annotated by librarians of the Slavic and East European Division of the University of Illinois Library at Urbana-Champaign, and the entries are signed with their initials. ${ }^{1}$ The highly selective list aims to include works which will be of significant reference value. To aid verification $\mathrm{Li}$ brary of Congress entries and card numbers are used when available.

\section{General}

Hunter, Brian. Soviet-Yugoslav Relations, 1948-1972: A Bibliography of Soviet, Western, and Yugoslav Comment and Analysis. Garland Reference Library in Social Science, vol. 18. New York: Garland Publishing, 1976. 223 pp. $\$ 20.00$. LC 75-24104.

This volume includes a listing of periodical articles and books treating relations between the Soviet Union and Yugoslavia. The bibliography is annotated, and articles are arranged chronologically within each of three sections representing the Soviet, Yugoslav, and Western points of view. The work contains author and subject indexes, a list of periodical titles from which articles were selected, and a chrónology of events, 1948-72.-HL.

Nowak, Chester Michael. CzechoslovakPolish Relations, 1918-1939: A Selected and Annotated Bibliography. Hoover Institution Bibliographical Series, 55. Stanford: Hoover Institution Press, 1976. xii, 219 pp. \$10.00. LC 75-39562. Based on Nowak's 1971 Boston University dissertation, this work contains 869 citations to bibliographies and published primary and secondary sources

1. Robert Burger, Marianna Tax Choldin, Harold Leich, Laurence H. Miller, June E. Pachuta, Dmytro Shtohryn. dealing with Czechoslovak-Polish relations. Literature published up to 1972 is included; all items are annotated, many in great detail. In addition to more general works on the two countries and works specifically dealing with their relations between 1918 and 1939, items are included on particular areas in conflict between the two nations, such as Teschen, Spis, Orava, Eastern Galicia, and Ruthenia. Use is facilitated by cross references and an author index.-HL.

Okinshevich, Leo. United States History and Historiography in Postwar Soviet Writings 1945-1970. Santa Barbara: ABC-Clio Press, 1976. xvi, 431 pp. \$27.50. LC 76-3756.

Okinshevich has compiled a bibliography of 3,699 items by Soviet writers, including monographs, periodical articles, dissertation abstracts, and reviews of American books and articles. Titles are transliterated, followed by English translations. Some items are annotated. Works are arranged topically within historical periods, with additional sections on U.S. cultural history, church and religion, U.S. archives, the history of particular regions and dependencies, miscellanea, and Soviet evaluations and criticism of American studies. There are indexes of Soviet authors, non-Soviet authors, and subjects; and two appendixes: a list of abbreviated names of publishing houses, and a list of the more than 300 periodicals cited.MTC.

Sanders, Irwin Taylor. East European Peasantries: Social Relations: An Annotated Bibliography of Periodical Articles. Compiled by Irwin T. Sanders, Roger Whitaker, and Walter C. Bisselle. Boston: G. K. Hall, 1976. vi, 179 pp. \$12.00. LC 76-19098.

Detailed abstracts and complete bibliographic citations to articles on the peasantries of Eastern Europe, based on the 
collection of articles on this subject at the Mugar Library, Boston University, are included in this work. The bibliography is arranged by country and includes a section for general articles dealing with more than one country. Yugoslavia and Poland are the areas most extensively represented.-HL.

\section{Bulgaria}

Rechnik na bŭlgarskata literatura. Vol. 1: A-D. Edited by Georgi Tsanev. Bŭlgarska akademiia na naukite. Institut za literatura. Sofia: BAN, 1976. 408 pp. 4.15 lv. LC 76-528325.

All aspects of Bulgarian literature from Old Bulgarian manuscripts to the works of contemporary authors are covered in this comprehensive dictionary. Articles on individual writers include listings of their works and bibliographies of works about them. There are also entries for literary periodicals and societies, movements, and genres and other terms. Two more volumes are projected.-JEP.

\section{RUSSIA AND Soviet UNION}

Bērsons, Ilgonis. Padomju Latvijas rakstnieki. Riga: "Liesma," 1976. 678 pp. 1.93 rubles. LC 77-504872.

Biographical sketches, including bibliographies, and portraits of 233 living and dead members of the Soviet Latvian writers' union are included in the work. The main alphabetical section includes Latvian authors, and there are separate sections for translators and Russian authors.-LHM.

Chereiskii, Lazar' Abramovich. Pushkin i ego okruzhenie. Leningrad: "Nauka," 1975. 519 pp. 3.12 rubles. LC 76-525863.

This biographical dictionary contains abbreviated biographical information on 2,500 of Pushkin's contemporaries with whom he had personal contact. Each entry includes bibliographical references.- $R B$.
Danielian, E. S. Bibliografiia $V$. Ia. Briusova, 1884-1973. Edited by K. D. Muratova. Erevan: Izdatel'stvo Erevanskogo universiteta, 1976. $501 \mathrm{pp}$. 1.80 rubles.

Over 4,300 items are included in this comprehensive bibliography. The first part lists Briusov's literary works, critical articles and reviews, translations, letters, and works edited by him, all in chronological order. Works published outside the Soviet Union are not included. The second section lists material on Briusov, also arranged by year of publication. Most items have brief annotations, and the contents of collections are fully listed. Several author and title indexes are included.JEP.

Dossick, Jesse John. Doctoral Research on Russia and the Soviet Union, 19601975: A Classified List of 3,150 American, Canadian, and British Dissertations with Some Critical and Statistical Analysis. Garland Reference Library of Social Science, vol. 7. New York: Garland Publishing, 1976. xxiv, 345 pp. $\$ 18.00$. LC 75-5115.

A continuation of the author's 1959 bibliography covering dissertations accepted from 1876 to 1959 , this volume lists dissertations accepted 1960-75 and includes some onitted from the earlier volume. The dissertations are arranged in twenty-one broad subject groups with subdivisions. References are given at the end of each section to relevant titles elsewhere in the bibliography. Indexes include the names of authors and Russian and Soviet personal names.-HL.

Grigorovich, Natal'ia Nikolaevna. Russkaia literatura $v$ sovetskoi muzyke: Spravochnik. Vol. 1: A-L. Compiled by N. N. Grigorovich and S. I. Shlifshtein. Moscow: "Sovetskii kompozitor," 1975. 466 pp. 2.11 rubles. LC 76-516033.

A continuation of Russkaia poeziia $v$ otechestvennoi muzyke do 1917 goda (Moscow, 1966), this work is broader in scope and includes selections from many 
literary genres. Soviet musical compositions from 1917 onward are listed. Entries are under the literary author and his work, followed by the composer and a full bibliographic description of the music, often including the date of first performance. An occasional mention is made of manuscripts, but generally only published musical works are cited.-JEP.

Istoriia dorevoliutsionnoi Rossii $v$ dnevnikakh $i$ vospominaniiakh: Annotirovannyi ukazatel' knig $i$ publikatsii $v$ zhurnalakh. Vol. 1: XV-XVIII veka. Edited by P. A. Zaionchkovskii. Compiled by G. A. Glavatskikh et al. Moscow: "Kniga," 1976.300 pp. 1.46 rubles. LC 76-532962.

Future volumes of this comprehensive scholarly bibliography will be published in parts over a period of several years and will cover Russian history to March 1,1917 as reflected in Russian memoir and travel literature published in Russia and the Soviet Union. This is by far the most ambitious historical bibliography on pre-Revolutionary Russia to reach fruition in the Soviet Union. The first volume has 867 carefully annotated entries, is well indexed, and includes a list of the serial publications examined during compilation of the work.-LHM.

Jones, David Lewis. Books in English on the Soviet Union, 1917-73: A Bibliography. Garland Reference Library of Social Science, vol. 3. New York: Garland Publishing, 1975. 331 pp. $\$ 30.00$. LC 75-6887.

The volume lists 4,585 books which are wholly concerned with the Soviet Union. To limit the size of the list most books which consider both the tsarist and Soviet periods and most pamphlets have been excluded. Books are arranged in eleven broad subject categories with further subdivisions, and there is a name index. The book is reproduced from an apparently unedited typescript with many inaccuracies, and the price seems exhorbitant. -RB
Kandel', Boris L'vovich. Russkaia khudozhestvennaia literatura $i$ literaturovedenie: Ukazatel' spravochno-bibliograficheskikh posobii s kontsa XVIII veka po 1974 god. By B. L. Kandel', L. M. Fediushina, and M. A. Benina. Moscow: "Kniga," 1976. 492 pp. 1.77 rubles. LC 77-506986.

This annotated listing of 2,522 bibliographies of Russian literature of all periods includes general literary and critical bibliographies and bibliographies of individual writers, topics, and literary critics. Titles include separately published bibliographies and those published as articles or parts of monographs. A 59-page index includes the names of authors whose bibliographies are in certain basic reference tools, but with some omissions (for example, Gumilev, Merezhkovsky, Zinaida Hippius). Also omitted are some basic well-known works of Russian literary bibliography (by B. P. Koz'min, Roza Mandel'shtam, and E. F. Nikitina) published in the 1920s.-HL, LHM.

\section{Miliband, Sofiia Davidovna. Biobiblio-} graficheskii slovar' sovetskikh vostokovedov. Moscow: "Nauka," $1975.732 \mathrm{pp}$. 9.32 rubles. LC 76-51735.

Biobibliographical information is provided on more than 1,400 Soviet scholars in Oriental studies active between 1917 and 1972. Included are biographical data, major works, dissertations, and also literature about each individual. The index is arranged by regions, countries, and subjects, and alphabetically by author within each section.-MTC.

Moscow. Publichnaia biblioteka. Otdel rukopisei. Vospominaniia $i$ dnevniki XVIII-XX vv.: Ukazatel' rukopisei. Edited by S. V. Zhitomirskaia. Moscow: "Kniga," 1976. 619 pp. 2.50 rubles. LC 77-505631.

The memoir and diary literature of 1,270 persons (mainly Russians) whose manuscripts are preserved at the Lenin State Library is listed and indexed in this work. Full bibliographic details are given 
for each manuscript, and indexes provide access to the manuscript contents by personal name, subject, periodical title, and geographic name.-HL.

Powell, Angelika Schmiegelow. Istoricheskie zapiski: Cumulative Index ( $A u$ thor and Subject), Volumes 1-90, 19371972. Nendeln: Kraus-Thomson Organization Ltd., 1976. 103 pp. SFr. 54.

Powell's index, a cumulation of the five "Ukazateli statei i materialov" published by the journal itself for volumes 1-20, $21-40,41-60,61-80$, and $81-90$, is divided into two parts. Part 1 is an alphabetical listing by author (in Cyrillic) of articles published in the journal for the period covered. Each citation provides complete title, volume, and page references. Part 2 is a subject index which uses slightly modified Library of Congress subject headings. This section (in transliteration) cites articles by author, volume, and pagination.- $-R B$.

Proffer, Ellendea. An International Bibliography of Works By and About Mikhail Bulgakov. Ann Arbor: Ardis, 1976. 133 pp. \$15.00. LC 77-351433.

This first book-length bibliography of Bulgakov is divided into sections containing his works in Russian, critical works about Bulgakov in Russian, publications in English (translations and criticism), translations into other languages, and critical works in other languages.-RB.

Rostov on the Don, Russia. Universitet. Slovar' russkikh donskikh govorov. 3 vols. Compiled by Z. V. Valiusinskaia et al. Rostov on the Don: Izdatel'stvo Rostovskogo universiteta, 1975-76. 4.58 rubles. LC 77-500207.

This dictionary of the Russian dialects of the Don region is based primarily on extensive field work begun in 1958, but also incorporates several earlier studies. At least one example is given of the use of each lexical item, phrase, and idiom. Volume 1 contains a short study on the characteristics and history of the Don dialects.-HL.
Russkaia literatura Sibiri XVII v.-1970 g.: Bibliograficheskii ukazatel'. Vol. 1. Compiled by D. P. Maslov et al. Novosibirsk: "Nauka," 1976. 548 pp. 2.04 rubles. LC 77-505629.

The first of two volumes containing some 5,700 citations concerning the development of Russian literature in Siberia, this bibliography lists general works, works by and about Siberian authors and those in exile, and works by those using Siberian themes. Books, chapters, journal and newspaper articles, and literary collections are cited. There are annotations, some of which include citations of critical works. The final section of this volume is devoted to Soviet literature in Siberia.JEP.

Russko-angliiskii meditsinskii slovar'. By

B. Eliseenkov et al. Moscow: "Russkii iazyk," 1975. 647 pp. 3.88 rubles. LC 76-502544.

About 50,000 Russian terms in medicine and related fields are included with English and often Latin equivalents in this useful new addition to the body of Russian to English scientific dictionaries.-LHM.

Treml, Vladimir G. Input-Output Anal$y$ sis and the Soviet Economy: An Annotated Bibliography. Praeger Special Studies in International Economics and Development. New York: Praeger Publishers, 1975.180 pp. $\$ 15.00$. LC 7315200.

This annotated bibliography, an updated and expanded edition of a version published in the Duke University-University of North Carolina Occasional Papers series, lists both Soviet and nonSoviet sources in the area of input-output analysis and related techniques in the USSR. The 934 items are arranged in seven broad categories with an author index.- $R B$.

Wytrzens, Gunther. Bibliographie der russischen Autoren und anonymen Werke. Zeitschrift für Bibliothekswesen and Bibliographie, Sonderheft 19. 
Frankfurt am Main: Vittorio Klostermann, 1975. xv, $267 \mathrm{pp}$.

This excellent handbook to Russian literary bibliography is particularly valuable for its selection of basic critical works and reference sources on individual Russian authors, its international coverage, and the inclusion of authors not covered by current Soviet bibliographies.I.HM.

\section{UKRAINE}

Pys'mennyky Radians'koi Ukrainy: Dovidnyk. Edited by P. Iu. Shabatin. Kiev: "Radians'kyi pys'mennyk," 1976. 416 pp. 1.70 rubles.

While previous editions included biobibliographies of all Soviet Ukrainian authors, this edition lists only contemporary writers and critics who are living in the Soviet Ukraine and are members of the Ukrainian writers' union. The directory has short biographies and compre- hensive bibliographies of 930 authors (including their portraits) who write in various languages (744 in Ukrainian, 150 in Russian, 20 in Ukrainian and Russian, 12 in Yiddish, and 4 in Hungarian).-DS.

Shevchenkivs'kyi slovnyk. 2 vols. Instytut literatury im. T. H. Shevchenka, Akademiia nauk URSR. Kiev: Ukrains'ka radians'ka entsyklopediia, 1976-77. 6.30 rubles.

This first serious attempt at a comprehensive dictionary of the greatest Ukrainian poet, Taras Shevchenko, comprises descriptions of all possible subjects (including persons and places) connected with his work as well as with him as a man, poet, novelist, and painter. It also includes biographical notes of authors and lists of their memoirs, critical studies, fiction, or poetry dealing with Shevchenko. Many illustrations, portraits, and maps are included. Numerous authors and their works about Shevchenko are omitted, apparently for ideological reasons.-DS. 